\title{
The Role of Communication in Effective Crisis Management: A Systematic Literature Reviews
}

\author{
Ezekiel Luka Zakiri \\ BA, MA and PhD Student \\ Adventist University of Africa \\ Nairobi, Kenya.
}

\begin{abstract}
In today's world, communication is an important component for effective crisis management for profit and non-profit organizations. Because the global world has become widespread, most organizations need to meet their needs but there is ineffective communication for effective crisis management globally which is affecting the workers' productivity in many organizations. Crisis management is coherent with the communication strategy in a crisis. In this systematic literature review, different kinds of literature were reviewed by different authors. However, the authors have tried to put forth the best practices to manage the crisis in a difficult situation for the smooth running of the organization. No crisis management can help in the smooth operations of the organizations unless some regulatory measures are put in place to meet the situation. The crisis is inevitable and unavoidable by any organization due to unforeseen events. Recommendations and suggestions make it very clear that maximum precautions can be taken to minimize the communication gap and the efforts by the top and middle-level management. So, preventive measures can be taken for smooth tackling of crisis to have minimum colossal damage to the organization.
\end{abstract}

Keywords: Communication, Crisis, Management

\section{Introduction}

Communication is a very crucial aspect of any organization. According to (McKinney, Barker, Smith \& Davis (2004), communication is essential to effective team performance and communications for any organization are like blood circulation in the human body. Therefore, any organization that understands the importance of communication uses it effectively for their benefit. It ensures coordination of factors of production and most importantly material and human elements of the organization as an efficient network of change and advancement. According to Snavely (2001), as cited by Robins (2006), the communication process is initiated through the sender-encoding-the message-the channel decoding-the receiver- noise and feedback. It is estimated that managers spend over $80 \%$ of their day communicating with others. Thus, most of the basic management process- planning, organizing, leading, and controlling - cannot be performed without effective communication.

In today's unprecedented times, organizations across sectors have to adapt to very challenging circumstances. Crisis management theories and concepts, as well as real-life case studies provide a wealth of information to act upon and draw from to best navigate the disruptive and unexpected events, public and private organizations are facing today. Crisesare unavoidable organization; be it profit or non-profit organization. Suchcrises could be a technical, economic, political, ethical, legal, or natural environmental crisis, that can harm an organization's reputation within a short period. Therefore, leadership has a greater role to play - by identifying potential sources of crises, planning, providing direction, making decisions, and managing emotions in a very tense environment. This can be done through effective communication because effective communication is the centerpiece of effective leadership. Furthermore, knowing fully that poor communication ranks as the single most important reason that people do not advance in their career (Lepsinger \& Luacia, 1997), it becomes necessary that organizations determine the best "channel" in transmitting "messages" to their staff for effective and positive feedback in a bid to manage crisis. There are many barriers to communication; filtering, selective perception, information overload, personal bias, language, and communication apprehension. Hence management must try to address these barriers for effective results.

Crisis management according to Coombs (2007) is a vital executive role. The result of failure can have grave harm to stakeholders, culminating in an organization or institution incurring extensive losses that can lead to its extinction. Hence it is important to stress that in communication, emotions, environment, psychological and technical characteristics of the medium are relevant to enhance organizational productivity. In the view of Okoye (2004), the psychological transmission goes beyond the reception of information but understanding and feedback. Mismanaged organizational crisis has been traced to breakage in communication (Lee, 2003; Scott, 2004). 
According to Chudi -Oji (2013), Despite the laudable roles of effective communication in improving organizational productivity, it is regrettable that some persons pay lip service to the maintenance of effective communication systems. Hence, this paper systematically reviews the role of communication in effective crisis management in organizationsin organizations. Before then, it is pertinent to raise a critical appraisal on defining concepts relevant.

\section{The Concept of Communication}

Communication is a crucial aspect of effective organizational management. On-going patterns of interaction among people within organizations are characterized as planned, sequential, and systematic. While communication is the connection among individuals, at the same time, it helps individuals in creating awareness (Neher, 1997). Cloke and Goldsmith (2000) stated those employees' reactions to the conflict may take different styles, such as litigation, strike, poor morale, or reduced productivity due to miscommunication. They believe that any type of conflict can be "avoidable" if the organization opens communication channels through dialogue. Ramah (1985) defines communication as the transmission and reception of ideas, feelings, and attitudes, verbally, or non-verbally to produce a favorable response. Draft (2000) defines communication as "the process by which information is exchanged and understood by two or more people usually to motivate on influence behavior". Communication refers to the exchange of information between a sender (source) and a receiver (destination) so that it is received, understood, and leads to action, ion (Obamiro, 2008). Obilade (1989) defines communication as "a process that involves the transmission of a message from the sender to the receiver. Folarin (2003) defines communication as "any means by which a thought is transferred from one person to another". Communication is the process by which any person or group shares and impacts information with/to another person (or group) so that both people (or groups) clearly understood one another (Soola, 2000).

According to Ince and Gül (2001), communication is the exchange of ideas, emotions, and opinions words, letters, and symbols among two or more people. He states that this may be defined as a technical fact. Yet it is uncertain whether symbols are transferred truly or not, to what extent symbols meet the transmitted message and how effectively transmitted fact on the receiver (Kalla, 2005; Baltas and Baltas, 2002). Without communication, through readings, listening (the receptive skills), speaking, and writing (the productive skills) people would find it difficult to unravel some of the mysteries of life. Those things that we are ignorant of or have knowledge of, or that we have doubts about can be explained to us better through communication. Altinöz (2008) defines communication as a means through which the task and the resources needed to carry out an assignment, the roles and duties, and the expected, results are made known to the subordinates. This means that communication is the transfer of information (a message) from one person to another. Thus, effective communication is therefore the transfer of message, followed by feedback, from the receiver to the sender, indicating an understanding of the message.

\section{The Concept Crisis}

Coombs (2007) defines crisis as a series of unwanted events at the place of work which leads to strife and major disorder amongst individuals. Crisis usually arises unexpectedly and triggers a feeling of danger and panic in the employees. Simply, crisis leads to doubt and causes major harm to the organization and its employees. It is, therefore, essential for employers to anticipate crises and forewarn their employees against the likely negative consequences that may emerge. Crisis not only affects the smooth operation of any organization it also poses danger to its brand name. Crises are unique moments in the history of organizations.

According to Regester (1995), crisis is a period within a system dynamic, characterized by the accentuated accumulation of difficulties, the conflicting outburst of tensions. Crisis involves an event, a revelation, an allegation, or a set of internal and external problems that threatens an individual's or an organization's integrity, reputation, or even existence Pricopie, (2005). Taneja (2014) explains that vandalism, or workplace violence, reputational such as rumors and gossip which can hurt the reputation of the organization can be a source of crisis. Unthinkable acts such as terrorist attacks, kidnapping or even tampering with products, and natural disasters including tornadoes, earthquakes, fire and flash floods, or outbreak of a disease can lead to crisis. Coomb (1999) advises organizations to classify them and each call for different response strategies. Lerbinger (1997) identifies these types as natural disasters, technological crisis, confrontational crisis, crisis of malevolence, crisis of organizational misdeeds, workplace violence, and rumors

\section{Factors Responsible for Crisis in An Organization}

Drawing from the types of crises present in organizations today the Management Study Guide website (2013) deduces the reasons for crises as follows: 1. A crisis occurs when employees in an organization fail to agree with each other on work-based policies, cross each other's boundaries, and end up fighting among themselves. 2. Technology-based letdowns and the collapse of machines in the organization lead to crisis. 3. 
Internet mishaps such as a poor internet connection, virus infection in computers (resulting in slow computer functions) password errors all end up in a crisis. 4. External or internal violence, terrorism as well as breaking at the workplace cause an organizational crisis. Therefore, the management of the organization should handle its personnel appropriately and not entertain a casual attitude at work. 5. Prohibited conduct such as fraud, bribery, tampering with organizational data, and/or information will eventually lead to the organization's unexpected collapse. 6 . Failure to submit remissions to the government in form of taxes, paying creditors, or claims to clients on time makes it easy for an organization to sink to bankruptcy.

\section{Crisis Management}

Crisis management is a process designed to reduce or prevent the damage that can inflict on an organization and its stakeholders. When viewing as a process, crisis management is not just one thing. Crisis management is based on risk management, namely, on "activities performed toward preventing and evaluating of events of various origins, without initiating prevention steps, but trying to diminish the chances of risk development, or by initiating protective steps, trying to reduce the risk effects (Regester, 2003). Effective crisis management helps to handle the threats sequentially. The primary concern in a crisis should be public safety. A failure to address public safety intensifies the damage from a crisis. Reputation and financial concerns are only considered after public safety remedy has been met. So, crisis management is designed to protect an organization and its stakeholders from threats and to reduce the impact felt by threats. Aktouf (1992) opines that, crisis management is the art of making decisions to head off or mitigate the effects of such an event, often while the event itself is unfolding. This often means making decisions about your organization's future while you are under stress and while you lack key pieces of information. Crisis management is designed to prevent or lessen the damage a crisis can inflict on an organization and its stakeholders. Crisis management is divided into three phases: the pre-crisis phase, in which the company will aim to prevent and prepare for a crisis, the crisis response phase, when the management will deal with the crisis, try to contain it and limit its damages, and the postcrisis phase, concerned with the long-term goal of recovery from damage and image restoration (Coombs, 2011). Failure to manage crisis can have grave harm to stakeholders, culminating in an organization or institution incurring extensive losses that can lead to its extinction.

\section{Phases of crisis}

Pre-crisis is usually the starting point of crisis management. It's a form of risk assessment, which is the process of identification, analysis and response to potential risks (Petru, 2013). It also consists of scanning and analyzing the environment to systematically identify, assess, quantify risks by the degree of importance. Then, prioritize the respective environmental risks to the organization, estimate the probability of a particular crisis occurring, its expected frequency and its potential impact on operations.

Crisis response: Is the "crisis mode" which characterized by short decision time, complexity, and ambiguity, since the risk of immediate damage is still present. Decisive action is needed, and efforts must be shifted into containing the crisis and minimizing damage bringing the situation under control as quickly as possible. The organization traverses a path of "observation, interpretation, choice, and dissemination-repeating the process steps numerous times"(Hale, Dulek\&Hale, 2005). The first step towards crisis containment is to assess the situation by quickly gathering as much accurate information as possible. Because multinationals can be faced with crises that transcend boundaries, and which therefore require transnational cooperation, it is important to define the scope of the crisis, meaning whether it's local, regional, or global.

Post-crisis: In the post-crisis phase, when the crisis eases down, the organization enters the final phase, the post-crisis phase, in which the risk is over and business is resuming as usual. Thus, the crisis is no longer the focal point of management's attention although it still requires some attention. Now the organization can focus its resources on recovering from the crisis and rebuilding trust and credibility by managing public perception. Recovery involves attempts to "learn from the event internally and "handle" the event externally." (Coombs, 2011).

The post-crisis phase looks for ways to better prepare for the next crisis and fulfills commitments made during the crisis phase and also aims to repair any reputational damage sustained during the crisis.

A crisis should be a learning experience, and the crisis management efforts should be evaluated to determine what needs to be improved. To do this, an organization may appoint a crisis evaluation team, which should be different from crisis management team members, to assess the handling of the crisis and recommend changes in crisis procedures. This will minimize crisis recurrence and damage, by integrating lessons learned into the organization's crisis management system. Such efforts will allow top management to improve prevention, preparation, and the response. 


\section{Crisis Communication and Effective Crisis Management}

Communication skill depends on the capability of an individual to communicate ideas and thoughts to others to develop the desired response. Communication is regarded as the most basic skill of a human being. From this point of view, communication is a product of a human being's survival. It is also a phenomenon that is easily affected by all sorts of developments and changes that have taken place in the way of being. In other words, communication-specific human patients (Oskay'ın, 1999). Communication is a key component to organizational success in dealing with crisis situations or events. In an organization, communication is the bond that binds all the actions and operations, internally and externally. Therefore, communication is critical to the effective performance of any enterprise (UONCP, 2014).

Communication plays a vital role in an organization and when a crisis occurs, the art of communicating should be carefully looked at, to avoid misguidance or miscommunication, especially from the media and the public. Moden (2008) asserts that communicating amid a crisis is more difficult than in everyday interaction. Effective communication, therefore, requires coordination, cooperation, and a great deal, of internal communication. It is imperative that in an organization, everyone should have good communication skills which will in turn enable them to achieve organizational goals and objectives and thereby to a larger extent minimize the possibility of crisis from occurring.

When crisis eventually occur in an organization, consistent and persistent communication becomes the organization's top priority. Depending on the exact nature of the crisis at hand, the team should determine how much detail is appropriate for different stakeholder groups to know, from board members to staff, volunteers, media, clients, or funders. (Moden, 2008) The crisis management team should be establishing a system that provides staff, clients, volunteers, and other key stakeholders with any information they may need before during and after a crisis.

According to Benoit (2010), there are certain communication strategies in crises: the negation strategy (by rejecting accusations); the responsibility denial (by declining charge of ability about certain events); the lessening of the dangerous action nature (by trying to obtain support, by reducing the negative sentiments, by differentiating, by transcending, attacking or compensating); the correction strategy (involving promises for Restauration, recomposition, etc.), and the humiliation strategy.

Coombs (2007), opines that the communication strategies in crises are classified into negation, outstripping, partiality, humiliation, and suffering. Once the action strategy has been established, the tactical steps need correlation with the action, based on logical sequencing; in other words, the solution to the problem (the analogical approach) must come into gradual steps (the digital approach), and respectively, for each of these steps, there must be specific objectives and action deadlines. Duncan \& Moriaty (1998) also argue that communication is a human activity that links people together and creates relationship. This means that individuals relate with each other through communication. The basic functions of management (planning, organizing, leading, and controlling), cannot be performed well without effective communication. The inability of managers of any organization to coordinate a perfect and smooth flow of communication interaction among employees and during crisis can affect the organization.

Cloke and Goldsmith (2000) differentiated between the types of communication, as well. They claim that some organizations communicate to settle a crisis, while others may communicate to resolve a crisis (p.12). Thus, organizations that are just interested in pacifying their employees, most likely have little interest in feedback and conflict resolution. On the contrary, organizations that encourage their employees to grow and learn usually are serious about conflict resolution. Open communication channels assist upper management to avoid negative reactions by the employees.

\section{The Importance of Communication in Effective Crisis Management}

When it comes to crises in the workplace, research shows that the areas that make employers most vulnerable are corporate reputation, cyber-crime, and rumors, supply chain issues, regulatory action, sexual harassment, and natural disasters as vulnerabilities as well. Effective communication protects employees and other stakeholders during a crisis, build trust in the workplace, Prevent the spread of misinformation in the workplace. Prevent panic and help employees feel secure, Prevent the threat a crisis may have on the organization's strategic objectives, reputation, and viability, align employees with the overall crisis management strategy and enable them to work towards the same goals, Align the internal and external messages. Keep customers loyal, Keep the reputation of being an attractive employer. 


\section{Conclusion}

In conclusion, regardless of where you live or the kind of work you do, many different types of crises have the potential to significantly disrupt your life. No community and no organization, is immune from crises. Understanding of internal and external risks that may have impact on the organization and ensuring that these risks are managed can mean the difference between success and failure for an organization. From the review hitherto, it is crystal clear that crisis management above all allows for renewal, stability, and growth after crisis situations, reduces earnings fluctuations, increases stakeholder confidence, protects the organization's assets and helps it meet insurance, legal and regulatory requirements, and avoids serious harm to stakeholders, losses for an organization, or end its very existence. In uncertain environments it can also give, you an edge over competition if the business is not disrupted. However, creative thinking determines the approach of crisis management not only as a business practice, but more, as a way of life and a more general mood, which carries the name of crisis culture. Besides, by its very nature, crisis management is multidisciplinary, and has psychological, social-political, and public relations elements which must all be taken into account. (J. Hale, Dulek, D. Hale,2005;). This means that a structured consideration of crisis must be built into existing activities and bean inherent part of key decision-making processes. Therefore, Baubion, (2012) concludes that, a crisis management plan must be continuously updated and philosophies must be able to change, to account for changes in external or internal factors, and to be improved.

\section{References}

Ada, N., Alver, A. Fatma, (2008). "Örgütsel_letisimin Örgütsel Baglllı Üzerine Etkisi: Manisa Organize Sanayi Bölgesinde Yer Alan ve_malat Sektörü Çalısanları Üzerinde Yapılan Bir Arastırma”, Ege Akademik Bakıs / Ege Academic Review 8(2), pp. 487-518.

Aktouf, O. (1992). Management and Theories of Organizations in the 1990s: Toward A Critical Radical Humanism? Academy of Management.

Altinöz, M. (2008). An Overall Approach to the Communication of Organizations in Conventional and Virtual Offices. Proceedings of World Academy of Science, Engineering and Technology. Vol. 31, ISSN 1307-6884

Baltas, Z., A. Baltas, (2002). Bedenin Dili, Remzi Kitabevi,_stanbul.

Kalla, H. K., (2005). "Integrated Internal Communications: A Multidisciplinary Perspective", Corporate Communications: An International Journal 10(4), pp. 302-314.

Benoit, W. L. (2010). Image repair discourse and crisis communication. Public relations review, 23(2), 177-180.

Baubion, Charles. (2012) Strategic Crisis Management." Organization for Economic Cooperation and Development. Public Governance and Territorial Development Directorate, 3 Dec. 2012. Web.

Coombs, W. T. (1999). Ongoing crisis communication: Planning, managing, and responding. Los Angeles: Sage

Coombs, W. T. (2007). Protecting organization reputations during a crisis: The development and application of situational crisis communication theory. Corporate Reputation Review, 10, 1-14

Coombs, W. Timothy. (2011) "Crisis Management and Communications." Institute for Public Relations. N.p., Jan.Feb. 2011. Web.

Cloke, K. \& Goldsmith, J. 2000, "Resolving conflicts at work", A complete guide for everyone on the job, Jossey-Bass, San Francisco, CA.

Chudi-Oji, C. (2013). Behavior Organization and Managing the Human Side of Work. Allyn and Bacon Inc; New York, 92-98.

Lee and Chuang (2009). The Impact of Leadership Styles on Job Stress and Turnover Intention: Taiwan Insurance Industry as an Example.

Delatte.J. (1993). How should sports organizations Handle a crisis? a focus on collegiate institutions Louisiana State University

Hale J, Dulek R, Hale D. (22005) Crisis Response Communication Challenges. Journal of Business Communication [serial online].42(2):112-134. Available from: Business Source Complete, Ipswich, MA

Lepsinger, R. \& Lucia, A. D, (1997). The Art and Science of 360 Feedback. California, US: PfeifferImp of Jossey-Bass Publishers

Lerbinger, O (1997). The crisis manager: Facing risk and responsibility. Mahwah, NJ: Lawrence Erlbaum.

McKinney, E.H, Barker, J.R, Smith, D. R \& Davis, K.J (2004). The role of communication values in swift starting action Teams: IT insights from flight crew experience, Journal of Information \& Management. 41(8), 10431056. Retrieved from,

http://www.sciencedirect.com/science/article/pii/S0378720603001721

Management Study Guide. (2013). Crisis Management - Meaning, Need, and its Features. Retrieved $16^{\text {th }}$ February 2015 from: http://www.managementstudyguide.com/crisismanagement.htm 
Mitroff, I. I, Harrington, K, \& Gai, E. (1996, September). Thinking about the unthinkable. Across the board,33(8), 4448

Neher, W. 1997, "Challenges of change, diversity and continuity, Organizational Communication”, Allyn and Bacon, Boston, MA.

Okoye, J.C (2004) Communication Effectiveness in Public and Private Organization. Enugu: HRV publishers.

Ojwang, R.A (2009). The effectiveness of public relations in the management of crisis: a case study of Safaricom

Olsen, W. (2012). Data collection: Key debates and methods in Social Research. London: SAGE

Patton, M.Q. (1990). Qualitative Evaluation and Research Methods. SAGE Publications. Newbury Park: London New Delhi

Robbins, S.P. (2006) Organizational Behaviour (11thed) New Delhi: Prentice-Hall of India Private Limited.

Register M. (1995). The practice of Public Relations, edited by Sam Black. 4th.ed. Butter worth Heinemann, Oxford.

Petru M. (2013) On the Role of Implementing A Database System in The Risk Communication Process. Young Economists Journal / Revista Tinerilor Economisti [serial online]. April 2013;10(20):255-258. Available from: Business Source Complete, Ipswich, MA. Accessed April 14, 2015.

Taneja S, Pryor M, Sewell S, Recuero A. Strategic Crisis Management: A Basis for Renewal and Crisis Prevention. Journal of Management Policy \& Practice [serial online]. February 2014;15(1):78-85. Available from: Business Source Complete, Ipswich, MA

Mclonglin, Barry (1996) Risk and Crisis Communication, Ottawa: McLonglin Multimedia Publishing Ltd, p.10 [7].

Pricopie, Remus (2005) Relaţiile publice: evoluţie şi perspective. Bucureşti: Editura Tritonic, seria Comunicare / Media, p.212 [17].

Regester, Michael, Larkin, Judy (2003) Managementul crizelor şi al situaţiilor de risc. Bucureşti: Editura comunicare.ro, p.28 [5], p.53 